\title{
Improvement of English Writing Skills through Blended Learning among University Students in Malaysia
}

\author{
Ayuni Madarina Abdul Rahman, Mohd Nazri Latiff Azmi, Isyaku Hassan* \\ Faculty of Languages and Communication, Universiti Sultan Zainal Abidin, 21300 Kuala Terengganu, Malaysia
}

Received October 11, 2020; Revised November 20, 2020; Accepted December 11, 2020

\section{Cite This Paper in the following Citation Styles}

(a): [1] Ayuni Madarina Abdul Rahman, Mohd Nazri Latiff Azmi, Isyaku Hassan, "Improvement of English Writing Skills through Blended Learning among University Students in Malaysia," Universal Journal of Educational Research, Vol. 8, No. 12A, pp. 7694 - 7701, 2020. DOI: 10.13189/ujer.2020.082556.

(b): Ayuni Madarina Abdul Rahman, Mohd Nazri Latiff Azmi, Isyaku Hassan (2020). Improvement of English Writing Skills through Blended Learning among University Students in Malaysia. Universal Journal of Educational Research, 8(12A), 7694 - 7701. DOI: 10.13189/ujer.2020.082556.

Copyright $\odot 2020$ by authors, all rights reserved. Authors agree that this article remains permanently open access under the terms of the Creative Commons Attribution License 4.0 International License

\begin{abstract}
The teaching and learning of writing involve developing the linguistic and communicative competence of students. Blended learning is described as a strategic and systematic approach that integrates the best aspects of face-to-face and online interactions using appropriate communication technology. This approach engages students in a tremendous learning experience through verbal and written communication. Therefore, this study aims to explore the benefits of blended learning in learning writing among university students using focus group interviews. The respondents consist of a purposively selected sample of six second-year students from Universiti Sultan Zainal Abidin (UniSZA), Malaysia. The interview data were analyzed using inductive thematic analysis. The findings show that the blended learning approach helps students to develop written communication skills, self-esteem, and interest in learning writing. The students viewed that this approach has provided them with the opportunity to learn in a flexible and conducive learning environment that has positive impacts on their writing. It is envisaged that this study would be beneficial to language instructors and education authorities by providing information that could be useful in the process of curriculum development, particularly for higher learning institutions.
\end{abstract}

Keywords Blended Approach, Communication, Interaction, Learning Outcome, Learning, Second Language, Writing

\section{Introduction}

Writing is a necessary skill in mastering the English language $[1,2]$. It is particularly critical in learning English as a Second Language (ESL) [3-7]. For ESL learners, writing is much more difficult, complex, and challenging to master than speaking, as it involves handwriting, spelling, flow, and punctuations, as well as the need to generate and organize ideas into comprehensible texts [8-11]. Students lack an understanding of the compositional aspect of English writing and do not view their English written texts as a means of communication [12].

Furthermore, studies revealed that students generally face difficulties while composing English writing [13, 14]. These problems occur because students are not satisfactorily acquainted with the English language and do not have adequate writing exercises. The major concerns in students' writing include grammatical, punctuation, and spelling problems [15]. As a result of these problems, researchers focus on how to improve students' English writing $[16,17]$. The integration of traditional learning approaches and technology to enhance students' writing skills is crucial [18, 19, 20]. Sarfo and Yidana [21] mentioned that "a combination of face-to-face and online instruction is termed as blended learning" (p. 145)

Blended learning is described as a strategic and systematic approach that integrates the best aspects of face-to-face and online interactions using appropriate communication technology [22, 23]. Hence, utilizing the blended learning approach in the educational environment 
could be useful [24]. Recent studies have focused on the blended approach to address difficulties in language learning [25-27] due to its various advantages. Regardless of some motivational and technology-related constraints, utilizing communication technology as a part of the classroom develops students' interest and trust in composing and upgrading their mechanical and social aptitudes. According to Mabuan and Ebron [26], the blended learning approach helps students to develop writing skills. As such, learners may acquire self-governance and enhance their dispositions toward English language learning.

Blended learning is required to help students fulfill the requirements of the working world [1]. This is because utilizing blended learning in the educational context can help students to develop positive learning outcomes [26, 28]. The blended learning approach is also useful in the area of English writing as it improves students' communication with their teachers, reduces communication anxiety, and motivates self-directed learners to improve their academic writing abilities [29]. Besides, blended learning engages students in a significant learning experience that suits their personal and academic interests [30, 31]. The blended learning approach supplements the traditional teaching method to ensure a learning environment that is appropriate to students' lives $[32,33]$. Despite the importance of blended learning in achieving positive learning outcomes, very few studies were conducted to explore its benefits, focusing on the Malaysian context from teachers' perspectives [34]. Therefore, this study aims to explore the perceived benefits of blended learning in learning writing among university students in Malaysia.

\section{Literature Review}

Research shows that blended learning is significantly related to students' satisfaction with the effectiveness of learning [35. 36]. In reality, communications technology is extensively utilized to meet various societal needs, including the need to address students' writing problems at different levels of learning [37]. For example, the Learning Management System (LMS) has become an important tool in the blended learning environment [38], especially for educational content delivery and management [39]. Several studies examined students writing in the ESL classroom using blended learning. For instance, Sahin [40] conducted research to investigate learners' perceptions of blended learning in tertiary institutions. The findings showed that effective learning tends to be achieved when face-to-face interactions are combined with Moodle interventions. Moodle was found to be effective in improving students' grammar and reading comprehension [41]

Blended learning is viewed as a new method of teaching that does not solely focus on teachers as information providers; it includes students as well. This mode of learning provides students with autonomy to progress while their achievements are supervised [25, 42]. To provide students with more appropriate access to quality learning experiences, educators need to discover effective and flexible delivery models instead of utilizing traditional learning methods alone [43, 44]. Supporting this point, Lloyd-Smith [45] mentioned that blended learning provides institutions with the opportunity to maximize classroom space and resources. Besides, blended learning offers flexibility for adult students who often have various commitments outside of the school environment. Through the blended learning approach, students could also improve their language skills and self-confidence [46, 47].

To achieve positive learning outcomes in the ESL classroom, students' English writing needs to be improved [13-14]. The blended learning approach could play a crucial role in this regard [26, 34]. According to Thirusanku and Yunus [1], blended learning is needed to enhance English language proficiency, especially among university students. Akkoyunlu and Soylu [48] found that students who developed positive perceptions of blended learning are likely to increase their engagement and become more active in the blended learning environment. Emelyanova and Voronina [27] believed that the blended approach is effective in developing self-directed learning and students' motivation intrinsically.

Furthermore, Yamin and Ishak [38] found that, in tertiary institutions, students have positive perceptions of blended learning, particularly LMS. The study confirmed the usefulness of blended learning in enhancing students' performance by supporting document sharing, which helps them to accomplish their tasks more quickly. In sum, previous studies affirmed that blended learning is utilized to improve learning outcomes $[35,40]$ due to its several advantages [26, 42, 44, 45]. Besides, the blended learning approach is proven to be more effective compared with the traditional methods as it is proven as more effective than the traditional methods [27, 40]. Annamalai [34] asserted that blended learning "shows greater effectiveness in learning outcomes compared to traditional classroom teaching" (p. 148). Therefore, the present study focuses on perceived benefits of blended learning in developing English writing skills among ESL students at a public university in Malaysia. The findings of this study could be useful in addressing students' difficulties, specifically in English writing.

\subsection{Blended Learning Tools}

The blended learning tools could be generally classified into three groups: LMS tools, social networking tools, and synchronized tools. LMS refers to web-based technologies such as Moodle and Blackboard that support the 
development, delivery, and assessment of particular learning material [49]. Social networking tools consist of Facebook, WhatsApp, Twitter, Skype, and Facebook used for discussion and sharing of educational content. The third category consists of the synchronized tools that are openly accessible, such as Dropbox, Google Apps, and Zoho Apps [50-52]. Nedeva and Dineva [53] stated that these online resources "have allowed people with common interests to meet, share ideas, and collaborate in innovative ways" (p. 471).

According to Wang [54], the implementation of blended learning tools in higher learning institutions promotes engagement and interaction among students and thus creates "a more learner-centered learning environment" (p. 842). Nedeva and Dineva [52] also mentioned that the blended learning approach utilizes flexible and collaborative communication tools to develop a content-specific platform. Besides, a study [51] shows that blended learning tools "are particularly used to support group members in editing online documents, along with exchanging thoughts and insights related to the subject matter" [p. 6]. Thus, instructors are encouraged to inspire their students to employ blended learning tools for formal learning activities and support them to possess online learning competencies [53, 55].

Most of the commonly used LMS have facilities that offer different forms of communication for collaborative knowledge construction [51, 54]. Students could access online materials and track their progress irrespective of where they reside [50]. Facebook, Twitter, Skype, and WhatsApp were found to be the most commonly used tools for collaborative learning purposes [51]. Besides, blended learning tools such as multimedia and web-platforms were found to be effective in improving teaching and learning experience [52]. Specifically, a study found that various blended learning tools, such as podcast and videocast, are successfully used to improve students' grammatical competence and communication $[56,57]$.

According to Sarfo and Yidana [21], blended learning tools are used to enhance critical thinking, communication, and collaborative skills. Moreover, a study [58] shows that most of "the tools used in blended learning are the same as those used in e-learning (p. 298). Various learning tools are combined to support learning activities to face the challenges of today's higher education [59]. Today, blended learning has evolved to encompass a much richer set of learning strategies such as live events, online content, collaboration, assessment, and reference materials [60].

\section{Methodology}

This study employed a qualitative approach in which focus group interviews were used to explore the perceived benefits of blended learning in developing ESL students' writing skills. Qualitative research is considered as this study aims to capture the students' actual believes [61]. This method enables researchers to provide in-depth insights into a problem and generate new ideas [62-64]. Focus group interviews are chosen as they enable researchers to gather more information in a relatively shorter time than could be gathered through individual interviews [63]. The study focuses on a case study of a public university in the State of Terengganu, Malaysia. A case could refer to an easily identified individual, group, situation, event, or ongoing process [61, 65]. According to Baxter and Jack [66], a case study mostly focuses on ongoing contextual phenomena.

\subsection{Data Collection}

A group of six ESL students from the chosen institution participated in this study. A sample of six to ten respondents is generally recommended for focus group interviews $[67,68]$. All of the participants were second-year ESL students who have taken English writing courses for two semesters through blended learning. These English writing courses integrate the traditional teaching approach with blended learning tools such as podcast, videocast, and online forum. The participants were purposively selected based on their experience of learning writing through the blended learning approach for at least one year. Purposive sampling involves selecting certain units based on a specific purpose [69]. In purposive sampling, researchers use their judgment to select a sample that could suit the research purpose [61]. A semi-structured interview was conducted with predetermined questions [70] on the blended learning approach. This kind of interview is useful in decreasing bias when different responses are compared [71]. Besides, semi-structured interviews could generate detailed information from the participants [63, 72]. The respondents were allowed to respond freely while specific questions were asked to clarify information that could arise during the interviews.

\subsection{Data Analysis}

Qualitative data analysis is practically interpretive as it is less a completely accurate representation as in the numerical tradition $[63,72]$. In this study, the interview data were analyzed using inductive thematic analysis based on the generalized four steps suggested by Cohen et al. [72]. These steps involve; 1) generating natural units of meaning; 2) classifying, categorizing, and ordering these units; 3) structuring narratives to describe the interview contents; 4) interpreting the interview themes. Only relevant responses obtained through the interviews were systematically deduced. The responses were analyzed based on their original connotations expressed by the 
respondents. The respondents were coded as R1, R2, R3, R4, R5, and R6 throughout the analysis.

\section{Findings}

The purpose of this study was to explore the benefits of blended learning in learning writing as perceived by a group of six ESL students at a public university in Malaysia. All the participants were between 18-21 years of age. Four of the participants were females while two of them were males. Also, the group represents the three major languages in Malaysia (Malay, Mandarin, and Tamil); two participants from each language background respectively. The students were asked to explain the perceived benefits of blended learning and how it helps them to develop English writing skills. The emerging themes from the students' responses are represented in Table 1.

As presented in Table 1, the dominant view of the respondents suggests that blended learning improves students' written communication skills (R1, R3, R5, R6) as well as their self-esteem in learning writing (R2, R3, R5, R6). The students believe that the blended learning approach enables them to organize their own pace of study and impacts their learning positively as they use podcasts, videocasts, and online forums to explore abundant writing potential. These perceptions are consistent with the findings reported by Sahin [40] that blended learning helps students to improve their communication and self-confidence. Furthermore, the respondents believe that their self-confidence in writing has improved after learning through the blended learning approach. In a similar context, Hall and Villareal [46] found that blended learning improves the level of students' motivation and self-confidence. Students develop self-confidence by engaging in online learning activities $[35,52]$. Nevertheless, the blended learning approach requires support from educators and the provision of learning materials based on the students' needs.

Moreover, the method of content delivery plays a vital role in regulating learning experiences [39]. In this regard, the respondents expressed that blended learning has increased their familiarity with writing using modern communication technology. These findings confirm that blended learning is positively associated with e-learning competence as pointed out by Mwakyusa and Mwalyagile [37]. When chosen appropriately, blended learning tools play a crucial role in developing students' interest and writing skills [32]. Similarly, Annamalai [34] found that students show their involvement in blended learning activities and improve their tech-savvy which resulted in positive learning behavior.

Table 1. Benefits of Blended Learning Approach

\begin{tabular}{|c|c|c|}
\hline Predetermined questions & Emerging themes & Exemplary quotes \\
\hline $\begin{array}{c}\text { Based on your blended learning } \\
\text { experience, what are the benefits of } \\
\text { blended learning in learning } \\
\text { writing? }\end{array}$ & $\begin{array}{l}\text { Improvement in writing } \\
\text { using technology }\end{array}$ & $\begin{array}{l}\text { It helps me to improve my English...R1 } \\
\text { It is so good for me that it improves my English skills...R5 } \\
\text { It helps me to improve my English learning...R6 } \\
\text { it improves my English learning and writing skills...R3 } \\
\text {...because it creates a learning experience through interaction } \\
\text { between students and lecturers and among students themselves...R6 } \\
\text { by helping me to develop self-esteem and self-confidence in } \\
\text { writing...R5 } \\
\text { by giving me the confidence to communicate...R3 } \\
\ldots \text { by increasing my self-confidence to communicate in English...R6 } \\
\ldots \text { as it makes me more confident when writing to other people...R5 } \\
\ldots \text { and make me brave enough to give an opinion...R5 } \\
\text { It gives me more confidence to communicate with other people...R2 } \\
\ldots \text { our class quiz and test are conducted online, so I become more } \\
\text { conversant with writing using online platforms...R1 } \\
\ldots . \text { I learn how to access resources on the internet to write and conduct } \\
\text { research...E2 } \\
\ldots \text { access to internet resources help me to improve my writing...R6 } \\
\text { I become more interested, focused, and excited about the writing } \\
\text { subject...R2 } \\
\text { It allows students to write at my own pace...R6 } \\
\ldots \text { provides ultimate flexibility in presenting content...R5 } \\
\text {...reduces classroom teaching time, then focuses on written } \\
\text { communication...R3 } \\
\text { It offers a multitude of real-world writing skills...R6 }\end{array}$ \\
\hline
\end{tabular}


Another theme that emerged from the interview data indicates that the blended learning approach makes learning writing flexible. This flexibility gives students the freedom to choose how and where they learn, thereby making learning a dynamic process [42]. Students' perceptions of blended learning are positive regarding its usefulness in terms of quality of writing instructions, course content, and flexibility. The blended learning approach has provided the students with better learning achievements, a higher level of enthusiasm, and more positive attitudes toward learning writing. According to Nedeva and Dineva [53], blended learning tools are convenient and easy to use as they have the flexibility of time and place. However, some students prefer having two-way communications with their classmates and lecturers while utilizing a blended learning approach for their writing skills. R1 stressed that "when we are divided into groups, we have so much fun to work together and share our experience to get good marks and support each other". According to Ghahari and Ameri-Golestan [19], the integration of technology with the traditional approach is effective in enhancing students' learning performance, especially in learning writing.

The blended learning approach has broadened the opportunities for students to exchange written ideas due to its varied learning activities. Eshreteh and Siraj [23] described that online lectures can enhance classroom collaboration between instructors and learners. Students tend to perform some writing activities to provide feedback to the wall post which encourages interactivity through writing [48]. During the interview session, R6 states "blended learning can help me to improve my interactions through writing feedbacks using emails, discussion boards and, chatroom". The use of online communication tools, such as Wikis, podcasts, and videocasts enhances individual and group involvement in the learning process which promotes communication and supports the dynamic teaching and learning process [51]. Thus, minimizing the teacher's role in the classroom has widened students' opportunity to interact through writing.

Bataineh and Mayyas [41] found that students were actively involved in blended learning activities provided on the Moodle online learning platform. Students can identify their strengths and weaknesses in writing and develop English communication skills [29]. They perceive interaction through blended learning positively. R6 explicated that "blended learning makes it easier for me to communicate with my colleagues and lecturers by composing my written messages freely". The findings of Andreeva and Ostroverkhaia [33] revealed the blended learning approach provides a non-threatening environment that enables students to prepare for the learning task. Similarly, Abu Bakar et al. [18] found that most students creatively expressed their written ideas using blogs.

In sum, the findings of this study showed that students of higher institutions perceive the blended learning approach positively as it helps them to develop their written communication skills and self-confidence. These findings agree with many previous studies that most students favored the blended learning approach $[38,46$, 48]. However, some studies indicate that students' preference toward the traditional learning approach is still high $[27,32]$. Thus, a balanced application between the traditional and blended learning approaches could be used to achieve better learning outcomes [40].

\section{Conclusions}

This study explored the perceived benefits of blended learning in improving English writing skills among ESL students in Malaysia. The findings revealed that the ESL students believe that blended learning helps them to develop their written communication skills, self-esteem, and interest in learning English writing. These findings indicate that blended learning could develop ESL students' writing skills through exchange of written information and access to various online reading materials. The students viewed the blended learning approach as an interactive and creative way of learning writing. According to them, the blended learning approach is a promising, creative, and feasible innovation in developing their learning experience by enriching support, activities, sources, and materials with a clear set of guidance and planning.

Through blended learning, students learn how to exchange written information, explain, clarify feedbacks on their learning task. However, the notion of blended learning does not aim to replace but rather supplement the teacher's role in the learning process. Thus, the integrated approach can produce positive learning outcomes in learning English writing. The findings of this study advance our understanding of the benefits of blended learning in improving English writing skills. This qualitative study is limited to a limited sample of six ESL students. Thus, the outcome of this study cannot be generalized. Further research may adopt a quantitative approach to provide more generalizable results.

\section{REFERENCES}

[1] J. Thirusanku and M. M. Yunus. "Status of English in Malaysia." Asian Soc. Sci., vol. 10, no 14, pp. 254-260, 2014.

[2] Z. Ahmadpour and R. Khaasteh. "Writing behaviors and critical thinking styles: The case of blended learning." Khazar J. Hum and Soc. Sci., vol. 20, no. 1, pp. 5-24, 2017.

[3] Z. A. Ahmad. Arabic writing skills among Malay students. UM Press, Malaysia, 2003.

[4] F. H. Aljumah. "Saudi learner perceptions and attitudes towards the use of blogs in teaching English writing course 
for EFL majors at Qassim University." Eng. lang. Teach., vol. 5, no. 1, pp. 100-116, 2012.

[5] S. Raoofi, S. H. Chan, J. Mukundan, and S. M. Rashid. "A qualitative study into L2 writing strategies of university students." Eng. lang. Teach., vol. 7, no. 11, 2014, pp. 39-45.

[6] S. Hussin, M. Y. Abdullah, N. Ismail, and S. K. Yoke. "The effects of CMC applications on ESL writing anxiety among postgraduate students." Eng. lang. Teach., vol. 8, no. 9, pp. 167-172, 2015.

[7] A. A. I. Challob, N. A. Bakar, and H. Latif. "Collaborative blended learning writing environment: Effects on EFL students' writing apprehension and writing performance." Eng. lang. Teach., no. 6, pp. 229-241, 2016.

[8] J. Myles. "Second language writing and research: The writing process and error analysis in student texts." Tesl-Ej, vol. 6 , no. 2, pp. 1-20, 2002.

[9] J. C. Richards and Renandya. Methodology in Language Teaching: An Anthology of Current Practice. Cambridge University Press, United Kingdom, 2002.

[10] H. A. Alsamadani. "The Effectiveness of Using Online Blogging for Students' Individual and Group Writing." Int. Edu. St., vol. 11, no. 1, pp. 44-51, 2018.

[11] A. Akhiar, A. Mydin, and S. A. A. Kasuma. "Students' perceptions and attitudes towards the use of Instagram in English language writing." Malaysian J. Learn. Instr, vo. 6, no. 1 , pp. 47-72, 2017.

[12] M. Mohite. An Investigation into the English Language Writing Strategies Used by Polish EFL Secondary School Learners. Master's thesis, London Metropolitant University, United Kingdom, 2014.

[13] S. Darus and K. Subramaniam. "Error analysis of the written English essays of secondary school students in Malaysia: A case study." Eur. J. Soc. Sci., vol. 8, no. 3, pp. 483-495, 2009.

[14] R. S. Dwivedi and R.V. Chakravarthy. Problems encountered by rural students in writing English: role of English teacher-some solutions. Int. J. Stu. Eng. Lang. Lit., vo. 3 , no. 7 , pp. $27-38,2015$.

[15] Z.B. Younes and F. S. Albalawi. "Exploring the most common types of writing problems among English language and translation major sophomore female students at Tabuk university." Asian J. Appl. Sci., vol. 3, no. 2, pp. 7-26, 2015.

[16] H. Rimbar. "The influence of spell-checkers on students' ability to generate repairs of spelling errors." J. Nus. St. (JONUS), vol. 2, no. 1, pp. 1-12, 2017.

[17] K. Mizusawa and T. Kiss. "Connecting multiliteracies and writing pedagogy for $21 \mathrm{st}$ century English language classrooms: Key considerations for teacher education in Singapore and beyond." J. Nus. St. (JONUS), vol. 5, no. 2, pp. 192-214, 2020.

[18] N. Abu Bakar, H. Latif, and A. Ya'acob. ESL Students feedback on the use of blogs for language learning, 3L. Sou. Asian J. Eng. Lang. St., 16 (1), 120-142, 2010.

[19] S. Ghahari and A. Ameri-Golestan. "The effect of blended learning vs. classroom learning techniques on Iranian EFL learners' writing." Int. J. For. Lang. Teach. Res., vol. 1, no. 3, pp. 77-86, 2013.

[20] A. Abdullahi, N. M. Rouyan, K. M. R. Almetairi, and I. Hassan. "Process-Oriented Writing via Computer-Mediated Peer-Reviewing: The Case of English Inner-Circle Learners of Arabic as a Foreign Language." Int. J. Sci. Tech. Res., vol. 9, no. 4, pp. 3043-3047, 2020.

[21] F. K. Sarfo and I. Yidana. "University lecturers experience in the design and use of Moodle and blended learning environments." Onl. J. New Hor. Edu., vol. 6, no. 2, pp. 143-154, 2016.

[22] G. Saliba, L. Rankine, and H. Cortez. Fundamentals of Blended Learning. Western Sydney University Press, Australia, 2013.

[23] K. M. Eshreteh and H. A. Siaj. "Attitudes of English-major students and teachers towards using blended learning in the English department at Hebron University." Int. J. Res. Eng. Edu., 2(4), pp. 51-65, 2017.

[24] N. Andreeva and I. V. Ostroverkhaya. "Learning to learn with blended learning." Eur. Sci. J., vol. 1, no. 2, pp. 193-203, 2017.

[25] J. K. Tarus, D. Gichoya, and A. Muumbo. "Challenges of implementing E-learning in Kenya: A case of Kenyan public universities." Int. Rev. Res. Op. Dis. Learn., 16(1), pp. 120-141, 2015.

[26] R. Mabuan and J. G. Ebron. "A blended learning approach to teaching writing: Using E-mail in the ESL classroom." Asian EFL J., vol. 4, no. 1, pp. 80-103, 2017.

[27] N. Emelyanova and E. Voronina. "Introducing blended learning in the English language classroom: Students' attitudes and perceptions before and after the course." Kno. Man. \& E-Learn., vol. 9, no. 1, pp. 33-49, 2017.

[28] W. Zhang, and C. Zhu. "Impact of Blended Learning on University Students' Achievement of English as a Second Language." Int. J. E-Learn., vol. 17, no. 2, pp. 251-273, 2018.

[29] M. Liu. "Blended learning in a university EFL writing course: Description and evaluation." J. of Lang. Teach. Res., vol. 4, no. 2, pp. 301-309, 2013.

[30] T. Krasnova and A. Ananjev. "Students' perception of learning in the online discussion environment." Med. J. Soc. Sci., vol. 6, no. 6, pp. 202-202, 2015.

[31] W. T. Y. Chan and C. H. Leung. "The Use of Social Media for Blended Learning in Tertiary Education." Univers. J. Educ. Res., vol. 4, no. 4, pp. 771-778, 2016.

[32] M. M. Yunus, N. Nordin, H. Salehi, M. A. Embi, and Z. Salehi. "The use of information and communication technology (ICT) in teaching ESL writing skills." Eng. Lang. Teach., vol. 6, no. 7, pp. 1-8, 2013.

[33] N. Andreeva and I. V. Ostroverkhaya. "Learning to learn with blended learning." Eur. Sci. J., vol. 12, no. 1, pp. 193-203, 2017.

[34] N. Annamalai. "How Malaysian lecturers view Mooc and its challenges." J. Nusan. St. (JONUS), vol. 4, no. 2, pp. 144-167, 2019. 
[35] W. M. Al-rahmi, M. S. Othman, and L. M. Yusuf. "The effectiveness of using e-learning in Malaysian higher education: A case study Universiti Teknologi Malaysia." Med. J. Soc. Sci., vol. 6, no. 5, pp. 625-625, 2015.

[36] U. K. Masrom, N. A. N. M. Alwi, and N. H. N. Asshidin. "Understanding Learners' Satisfaction in Blended Learning among Undergraduate Students in Malaysia." Univers. J. Educ. Res., vol. 7, no. 10, 2233-2238, 2019.

[37] W. P. Mwakyusa and N. V. Mwalyagile. "Impediments of E-Learning Adoption in Higher Learning Institutions of Tanzania: An Empirical Review." J. Edu. Prac., vol. 7, no. 30, pp. 152-160, 2016.

[38] F. M. Yamin and W. H. W. Ishak. "Does the blended learning and student-centered learning method increase student's performance." ISS Conf. Proc., July, 2017.

[39] E. Omwenga, T. Waema, and P. Wagacha. "A model for introducing and implementing e-learning for delivery of educational content within the African context." African J. Sci. Tech., vol. 5, no. 1, pp. 35-48, 2004.

[40] Sahin, K, A. "Blended instruction for EFL learners: Engagement, learning and course satisfaction." Jalt Call J., vol. 10, no. 3, pp. 175-188, 2014, 2014.

[41] R. F. Bataineh, and M. B. Mayyas. "The utility of blended learning in EFL reading and grammar: A case for Moodle." Teach. Eng. Tech., vol. 17, no. 3, pp. 35-49, 2017.

[42] J. Rhode. "Interaction equivalency in self-paced online learning environments: An exploration of learner preferences." Int. Rev. Res. Op. Dist. Learn., vol. 10, no. 1, pp. 1-23, 2009.

[43] B. Collis and J. Moonen. "Flexible learning in a digital world." J. Op. Dist. E-Learn., vol. 17, no. 3, pp. 217-230, 2002.

[44] L. D. George-Walker and M. Keeffe. "Self-determined blended learning: A case study of blended learning design." High. Educ. Dev. Res., vol. 29, no. pp. 1, 1-13, 2010.

[45] L. Lloyd-Smith. "Exploring the advantages of blended instruction at community colleges and technical schools." MERLOT J. Onl. Learn. Teach., vol. 6, no. 2, pp. 508-515, 2010 .

[46] S. Hall and D. Villareal. "The Hybrid Advantage: Graduate Student Perspectives of Hybrid Education Courses." Int. J. Teach. Learn. High. Edu., vol. 27, no. 1, pp. 69-80, 2015.

[47] A. M. Pinto-Llorente, M. C. Sánchez-Gómez, and F. J. García-Peñalvo. "A mixed methods research of pre-service teachers' perceptions about the benefits of Wiki-based tasks and discussion boards." ISQR Conf. Proc., June, 2017.

[48] A. Akkoyunlu and M.Y. Soylu. "A study of student's perceptions in a blended learning environment based on different learning styles." Int. J. Edu. Dev. Info. Comm. Techn., vol. 2, no. 11, pp. 80-100, 2015.

[49] N. A. Alias and A. M. Zainuddin. "Innovation for Better Teaching and Learning: Adopting the Learning Management System." Mal. Onl. J. Instruc. Tech., vol. 2, no. 2, pp. 27-40, 2005 .

[50] M. Wang, Y. Chen and M. J. Khan. "Mobile cloud learning for higher education: A case study of Moodle in the cloud." Int. Rev. Res. Op. Dist. Learn., vol. 15, no. 2, pp. 254-267, 2014.

[51] H. Al-Samarraie and N. Saeed. "A scoping review of cloud computing tools for collaborative learning: Opportunities and challenges to the blended-learning environment." Comp. \& Edu., vol. 12, no. 4, pp. 77-91, 2018.

[52] K. E. Kakosimos. "Example of a micro-adaptive instruction methodology for the improvement of flipped-classrooms and adaptive-learning based on advanced blended-learning tools." Edu. Chem. Eng., vol. 12, no. 1, pp. 11-1, 2015.

[53] V. I. Nedeva and S. B. Dineva. "Blended learning and applying new tools and services of E-learning support." Comp. Tech. App., vol. 3, no. 7, pp. 471-476, 2012.

[54] M. J. Wang. "Online collaboration and offline interaction between students using asynchronous tools in blended learning." Aust. J. Edu. Tech., vol. 26, no. 6, pp. 830-846, 2010.

[55] P. Reynold, G. Ruth, and T. Lucero. When Technology Disrupts Teaching and Learning: A Private Higher Education Students' Perceptions on the Challenges of Technology-based Teaching Tool. Univers. J. Educ. Res., vol. 7, no. 11, pp. 2293-2302, 2019.

[56] M. G. Brown. "Blended instructional practice: A review of the empirical literature on instructors' adoption and use of online tools in face-to-face teaching." Inter. High. Edu., vol. 31, mo. 2, pp. 1-10, 2016.

[57] A. M. Pinto-Llorente, M. C. Sánchez-Gómez, F. J. García-Peñalvo, and S. Casillas-Martín. "Students' perceptions and attitudes towards asynchronous technological tools in blended-learning training to improve grammatical competence in English as a second language." Comp. Hum. Behav., vo. 72, no. 1, pp. 632-643, 2017.

[58] M. Roszak, B. Kołodziejczak, W. Kowalewski, and A. Ren-Kurc. "Academic blended learning-competences and tools." Int. J. Conti. Eng. Edu. Life Long Learn., vol. 24, no. 3, pp. 286-301, 2014.

[59] N. Hoic-Bozic, M. H. Dlab, and V. Mornar. "Recommender system and web 2.0 tools to enhance a blended learning model." IEEE Trans. Edu., vol. 59, no. 1, pp. 39-44, 2015.

[60] C. C. Wai and E. L. K. Seng. "Exploring the effectiveness and efficiency of blended learning tools in a school of business." Proc. Soc. Behav. Sci., vol. 123, no. 1, pp. 470-476, 2014.

[61] J. R. Fraenkel, N. E. Wallen, and H. Hyun. How to Design and Evaluate Research in Education. McGraw Hill Publisher, United States, 2012.

[62] W. Hollway and T. Jefferson. Doing qualitative research differently: Free association, narrative and the interview method. Sage Publications, United States, 2000.

[63] J. W. Creswell. Research Design: Qualitative, Quantitative and Mixed Method Approaches. SAGE publications, United Kingdom, 2012.

[64] P. Aspers and U. Corte. "What is qualitative in qualitative research." Qual. Socio., vol. 42, no. 2, pp. 139-160, 2019.

[65] Z. Zainal. "Case study as a research method. J. Hum., vol. 5, 
no. 1, pp. 1-6, 2007.

[66] P. Baxter and S. Jack. "Qualitative case study methodology: Study design and implementation for novice researchers." Qual. Rep., vol. 13, no. 4, pp. 544-559, 2008.

[67] J. A. MacIntosh. "Focus groups in distance nursing education." J. Adv. Nur., vol. 18, no. 12, pp. 1981-1985, 1993.

[68] M. N. L. Azmi, I. Hassan, E. M. T. B. E. Ali, A. T. Hidayah, M. H. Y. Alias, M. B. Anas, and N. I. Suhaimi. "English Language Learning, Environment, and the Formation of Islamic Self-identity among Students in Selected Religious Secondary Schools." Int. J. Innov. Creativity Chang., vol. 11, no. 7, pp. 466-482, 2020
[69] Etikan, S. A. Musa, and R. S. Alkassim. "Comparison of convenience sampling and purposive sampling." American J. Theo. Applied Stat., vol. 5, no. 1, pp. 1-4, 2016.

[70] M. N. L. Azmi, I. Hassan, E. M. T. E. Ali, A. T. Hidayah, M. $\mathrm{R}$ Anas and $\mathrm{N}$ I Suhaimi "Teachers' Percentions of Islamic Self-Identitv Formation through I anouage I earning among Students in Selected Religious Secondary Schools." Int. J. Soc. Cult. Lang., vol. 8, no. 1, pp. 82-91, 2020.

[71] M. Sewell. The Use of Qualitative Interviews in Evaluation. The University of Arizona Press, United States, 2008.

[72] L. Cohen, L Manion, and K. Morrison. Research Method in Education. Routledge, United States, 2007. 